\title{
Adsorption of Natural Dyes on Clay Fixed on Polymers
}

\author{
Toni Jefferson Lopes ${ }^{1}$, Odinei Hess Gonçalves ${ }^{2}$, Ricardo Barbosa Barros ${ }^{1}$, Francine Carla \\ Rodrigues Capelli ${ }^{1}$, Ricardo Antonio Francisco Machado ${ }^{1}$, Mara Gabriela Novy Quadri ${ }^{1}$ \\ and Marintho Bastos Quadri ${ }^{{ }^{*}}$ \\ ${ }^{I}$ Departamento de Engenharia Química e de Engenharia de Alimentos; ${ }^{2}$ Programa de Pós Graduação em Ciência e \\ Engenharia de Materiais; Universidade Federal de Santa Catarina; Campus Universitário, Trindade; C. P.476; \\ 88040-900; Florianópolis -SC -Brasil
}

\begin{abstract}
The main purpose of this work was to produce a pellet to minimize undesirable effects in fixed beds, such as colmatation, through clay fixation on the surface of polymeric particles. Preliminary experiments were carried out by heating the clay, namely Tonsil Terrana 580FF, in order to observe variations on its capacity to adsorb anthocyanins derived from red cabbage. Clays was fixed on five samples of high density polyethylene (HDPE) at $180^{\circ} \mathrm{C}-210^{\circ} \mathrm{C}$ for two hours. The morphological analyses of the resulting particles were accomplished through Scanning Electron Microscopy (SEM). The experiments demonstrated an increase on clay's adsorptive capacity of $15.65 \%$ at $120^{\circ} \mathrm{C}$ for 30 hours and $16.80 \%$ at $170^{\circ} \mathrm{C}$ for two hours. The SEM analysis showed that the clay particles adhered on the external surface of the pellets.These results show that it is possible to obtain polymeric pellets using HDPE coated with clay.
\end{abstract}

Key words: Adsorption; clay; polymer; anthocyanin, red cabbage

\section{INTRODUCTION}

Food industry has used dyes of synthetic origin, but progressive restrictions given by legislation (FAO/WHO, FDA and of Secretaria Nacional de Vigilância Sanitária do Ministério da Saúde do Brasil) on red amaranto and some blue dyes contributed to stimulate the research natural and non-toxic dyes. This matter has leading to an increasing interest in natural dyes as a substitute of synthetic ones in recent years, due to their properties, especially considering their beneficial effects on biological systems (Aruoma, 2003; Renaud and De Lorgeril, 1992).

Anthocyanins are natural dyes that belong to the flavonoid group (Peterson and Dwyer, 2000).
They are water soluble, and are responsible for the blue, red, violet and purple colorations in several plants (Stringheta, 1991). These dyes can be partially or totally purified by adsorption process. Among the adsorbents normally used in this process, clay has been an important material due to its good sorption capacity. Clays are characterized by particles with a fine and very porous structure. Its porosity may reach values as high as $50 \%$ of the whole volume of the particle (Geankoplis, 1993). Clay also presents the swelling phenomenon that happens when particles of clay are humidified (Van Olphen and Fripiat, 1979; Neuman et al, 2000). Continuous processes in the fixed bed frequently use adsorbent materials that

\footnotetext{
* Author for correspondence
} 
cause some difficulties such as colmatation, head losses and compactation of the bed.

This work aims to accomplish a new technology with the purpose to achieve a new adsorbent material that could minimize these difficulties. Tonsil Terrana 580FF clay was adhered on polymeric beads of high density polyethylene (HDPE), for subsequent use in separation and purification by adsorptive processes of natural dyes.

\section{MATERIAL AND METHODS}

\section{Material}

Tonsil Terrana 580FF clay was supplied by Süd Chemie do Brasil Ltda. It is smectitic natural clay and its chemical composition and physical properties are presented in Table 1. Commercial dye from red cabbage was supplied by Christian Hansen Comércio e Indústria Ltda. Five samples of high density polyethylene (HDPE) pellets (mean diameter of $3 \mathrm{~mm}$ ) were supplied by IPIRANGA PETROQUIMICA S.A and Solvay Polietileno Ltda, Brazil.

\section{Thermic treatment of the clay}

Tonsil Terrana 580FF clay was thermically treated in an oven with temperatures varying from 60 to $170^{\circ} \mathrm{C}$ for two hours, and at $120^{\circ} \mathrm{C}$ at the heating times of 1, 2, 3, 5, 10, 24 and 30 hours. Static experiments using anthocyanin from red cabbage were made to test the variation of the adsorption capacity of the clay

Table 1 - Physical properties and chemical composition of Tonsil Terrana 580FF clay

\begin{tabular}{cc}
\hline Properties & Quantification \\
\hline $\begin{array}{c}\text { Apparent specific mass } \\
\left(\mathrm{Kg} . ~^{-3}\right)\end{array}$ & $850-950$ \\
Free acidity $\left(\% \mathrm{H}_{2} \mathrm{SO}_{4}\right)$ & -- \\
Humidity (humid basis) & $6.0-10.0$ \\
\hline Average Chemical Composition & $\%$ in Mass \\
Silicium Oxide & $42.0-60.0$ \\
Aluminum Oxide & $16.0-20.0$ \\
Iron Oxide & $6.0-10.0$ \\
Calcium Oxide & $1.0-8.0$ \\
Magnesium Oxide & $1.0-8.0$ \\
Titan Oxide & $0.4-3.0$ \\
Potassium Oxide & $0.3-3.0$ \\
Sodium Oxide & $0.3-3.0$ \\
\hline
\end{tabular}

Source: Süd Chemie do Brasil Ltda.

\section{Pellets manufacturing}

HDPE beads were mixed with clay and heated at the nominal softening temperatures of 180,190 and $210^{\circ} \mathrm{C}$ for two hours in an oven. The pellets were washed and dried to get off the excess of clay's particles that did not stick on the polymer. The ratio mass of clay/polymer was 1:1.

\section{Static adsorption experiments}

Static experiments were carried out with a known mass of clay, or pellets of clay, mixed with $50 \mathrm{~mL}$ of a solution of $3 \mathrm{mg} \mathrm{mL}^{-1}$ of the commercial dye from red cabbage on a magnetic stirrer for 30 minutes. Buffer solutions were used to maintain the $\mathrm{pH}$ at the desired value (Lopes, 2002). Desorption was done for 30 minutes using ethanol, water and citric acid (70:30:5 V/V/w). The determination of the dye concentration in the liquid samples was made using a spectrophotometer at $550 \mathrm{~nm}$. Concentration was obtained by using a standard curve of the commercial dye.

\section{Particle's morphology}

The images used to observe morphology of the particles was obtained through Scanning Electron Microscopy (SEM). Liquid nitrogen was applied 
to rupt and promoted a good exposure of the polymeric matrix. SizeMeter ${ }^{\circledR}$ Software was used to evaluate the clay's thickness adhered on the external surface of the polymer beads.

\section{RESULTS AND DISCUSSION}

\section{Adsorption capacity of Tonsil Terrrana 580 FF clay}

Fig. 1 shows the variation of the adsorbed dye on clay as a function of the treatment temperature at an initial concentration of $3.0 \mathrm{mg} \mathrm{mL}^{-1}$. Standard deviations are shown in the figure. There was a clear increase in the mass of dye adsorbed. Between $60-170^{\circ} \mathrm{C}$ the difference in the adsorbed mass was $16.8 \%$. However a mass loss of clay was observed at different temperatures (Fig 2). This could be due to the humidity loss, and to the degradation of the organic matter. Minimum and maximum values were $95.3 \pm 0.1 \%$ and $92.4 \pm 0.5 \%$, when temperature increased to $110^{\circ} \mathrm{C}$, and showed a stabilization around $93 \%$.

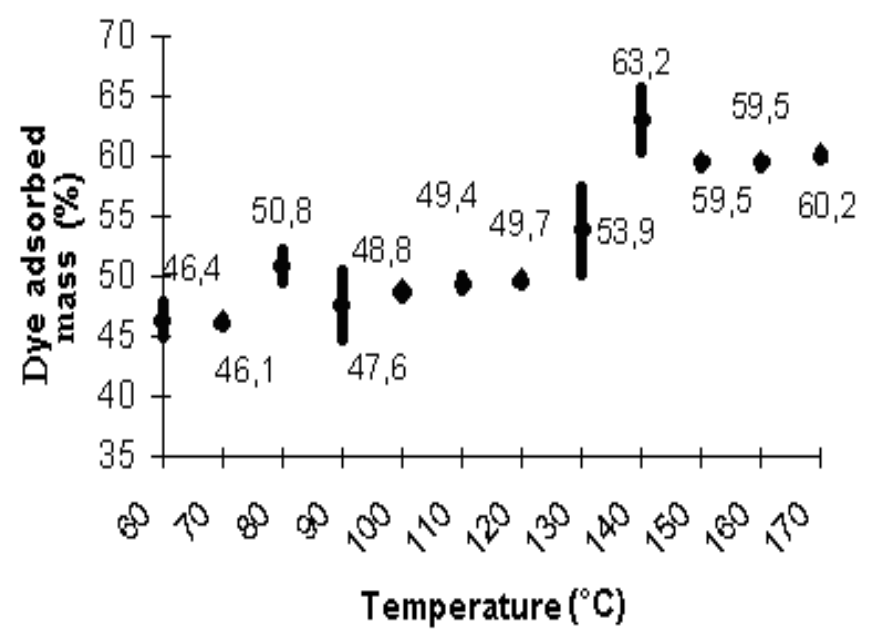

Figure 1 - Clay adsorption capacity after thermic treatment.

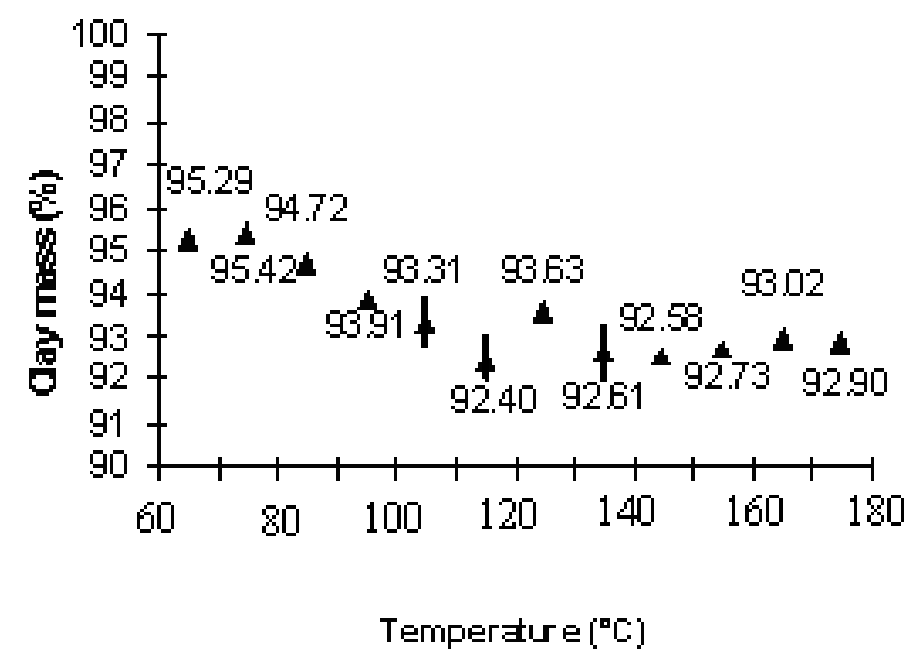

Figure 2 - Mass loss of clay. 


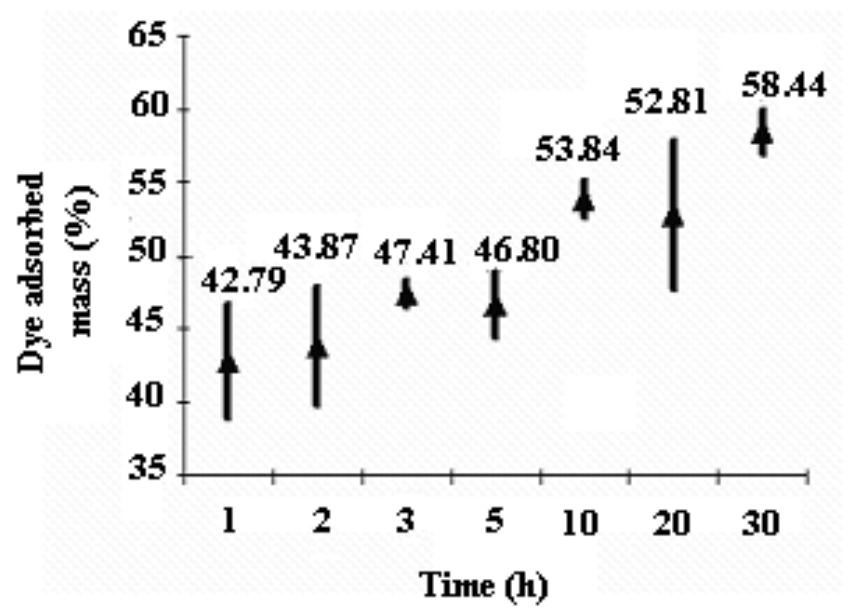

Figure 3 - Dye adsorbed mass at $120^{\circ} \mathrm{C}$

Thermic treatment had a beneficial effect on the adsorption capacity of the clay. Fig. 3 shows the kinetics of clay adsorption at $120^{\circ} \mathrm{C}$. An increase of $15.65 \%$ in the dye adsorbed mass was observed when the heating time increases from 1 to 30 hours.

It was observed that clay darkened at the particles surface, probably due to oxidation reactions caused by the oxygen and high temperature. This phenomenon was also observed by Reed (1995). Oxidation of the organic matter adhered to the clay particle was probably followed by an increasing in the active sites available for adsorption. This explained the increase of clay adsorptive capacity when it was thermically treated.

\section{Manufacturing the pellets}

Tests of fixation of clay on surface of HDPE made in five samples with different specific mass, temperature were chosen considering technical specifications of the supplier (Table 2), which showed that for similar HDPE mass, sample 4 presented the higher adhered mass of clay. However, sample 4 showed also a strong melting, with interparticle adhesion, resulting in a grainy structure. Many individual pellets also deformed into a cap, loosing its spherical form. Results indicated sample 5 as a possible support of adsorbents.

\section{Static adsorption experiments}

Adsorption experiments of natural dye were conducted using pellets from sample 5, which presented better performance during fixation process. Table 3 shows the results for an initial concentration of $1 \mathrm{mg} \cdot \mathrm{mL}^{-1}$. Apparenth with the increase in the mass of clay adhered on HDPE rises, the dye adsorbed also increases, approximately in a linear way. The best adsorption was found for $20.0 \mathrm{~g}$ of pellets of the sample 5 . Around $67 \%$ of the dye mass initially present in the solution was adsorbed, showing that the pellets had a good performance in absorbing anthocyanins of red cabbage.

Table 2 - Characteristics and results for the samples of obtained pellets (clay+ polymer).

\begin{tabular}{ccccc}
\hline Sample & $\boldsymbol{\rho}_{\text {polymer }}\left(\mathbf{g} / \mathbf{c m}^{\mathbf{3}}\right)$ & Temperature $\left({ }^{\circ} \mathbf{C}\right)$ & Clay adhered $\left(\mathbf{g ~ g}^{\mathbf{- 1}}\right)$ \\
\hline 1 & 1.000 & 180 & 0.092 \\
2 & 0.946 & 190 & 0.083 \\
3 & 0.948 & 190 & 0.100 \\
4 & 0.952 & 210 & 0.135 \\
5 & 0.954 & 210 & 0.119 \\
\hline
\end{tabular}


Table 3 - Adsorption static experiments on pellets

\begin{tabular}{c|c|c|c}
\hline $\begin{array}{c}\text { Pellets } \\
\text { (clay+polymer) }\end{array}$ & Pellets mass clay+polymer (g) & $\begin{array}{c}\text { Clay mass } \\
(\mathbf{g})\end{array}$ & $\begin{array}{c}\text { Percentile of adsorbed } \\
\text { dye mass } \mathbf{( \% )}\end{array}$ \\
\hline & 5.00 & 0.595 & 14.00 \\
Sample 5 & 10.00 & 1.188 & 35.88 \\
& 15.02 & 1.787 & 49.01 \\
& 20.00 & 2.380 & 67.61 \\
\hline
\end{tabular}

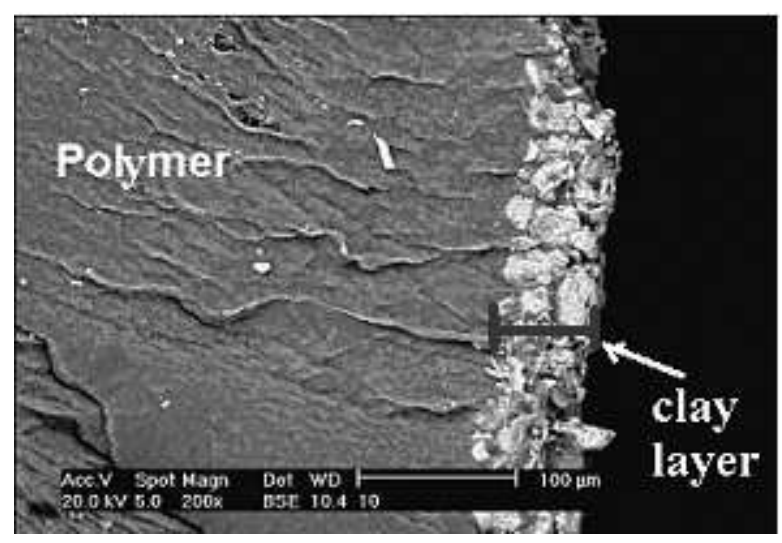

Figure 4 -Polymer's particle with clay adhered on the surface (magnification $200 \mathrm{x})$.

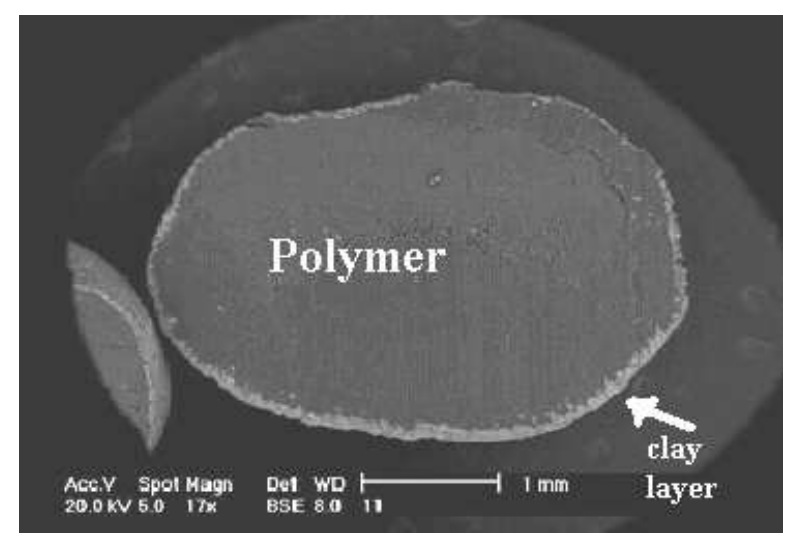

Figure 5 - Polymer's particle with clay after desorption process of natural dye (magnification 20x).

\section{Particle's morphology}

Images from Scanning Electronic Microscopy with magnification of 200 and 20 times were taken from the pellets before and after adsorption process. Fig. 4 shows a micrograph of a cut particle with fixed clay on the surface. It was seen that clay inserted on the surface (HDPE permeating the layer of clay particles). This confirmed that fixation occurred because the melting of HDPE allowed clay to mix with the polymer. The control of the time and temperature on a specific polymer determines how much clay can be inserted into beads, and consequently how many sites stay available for adsorption. It is important to consider that heat also increases the 
adsorption capacity of the clay, and a possible combined effect occurs when the pellet is formed.

Layer thickness was evaluated using tree particles. Thirty measures were taken from each one. The mean value found was $55.848 \pm 6.729 \mu \mathrm{m}$.

Fig. 5 shows the micrograph of the pellets after the dessorption process of dye. A diminution of the layer thickness was observed, although a significant part of the particles of Tonsil Terrana 580 FF clay remained on the HDPE beads surface. Thickness layer measured was $28.354 \pm 8.226 \mathrm{~nm}$. It was around $50 \%$ of the clay layer after the desorption process.

\section{CONCLUSIONS}

Thermal treatment increased the adsorption of clay about 15\%. Manufactured pellets presented a homogeneous fixation on the clay surface. It was observed that layer thickness was reduced around $50 \%$ after the adsorption-dessorption process. Some advantages in using the pellets of HDPEclay with regard to the original adsorbent were noted, such as sedimentation and separation in static process happened quickly and easily, without need of flocculant addition and/or use of centrifugation.

\section{RESUMO}

O objetivo deste trabalho foi estudar formas de minimizar efeitos indesejáveis como a colmatação em leitos constituídos de argila através de sua fixação sobre a superfície de partículas poliméricas. Foram realizados ensaios preliminares aquecendo a argila Tonsil Terrana $580 \mathrm{FF}$ em estufas para se observar a variação da sua capacidade de adsorção de antocianinas de repolho roxo. Posteriormente, foram utilizadas 5 amostras de polietileno de alta densidade para a fixação da argila a temperaturas de $180^{\circ} \mathrm{C}-210^{\circ} \mathrm{C}$ durante 2 horas. As análises morfológicas das partículas obtidas foram realizadas através de microscopia eletrônica de varredura. Os experimentos preliminares demonstraram um incremento máximo de $15,65 \%$ na capacidade adsortiva da argila $\left(120^{\circ} \mathrm{C}, 30\right.$ horas $)$ e $16,80 \%$ $\left(170^{\circ} \mathrm{C}, 2\right.$ horas). Estes resultados mostram que é possível obter pellets com depósito de adsorventes de fina granulometria fixados superficialmente.

\section{REFERENCES}

Agência Nacional De Vigilância Sanitária. (2001), Available at: http://www.anvisa.gov.br. Access on: Nov. 2001.

Aruona, O. I. (2003), Methodological considerations for characterizing potential antioxidant actions of bioactive components in plant foods. Mutation Research, 523-524, 9-20.

Geankoplis, C. J. (1993), Transport Process and unit operations, Prentice-Hall. pp. 697-707.

Lopes, T. J. (2002), Adsorção de Antocianinas do repolho roxo em argilas. Dissertação, UFSC, Florianópolis-Brasil.

Neumann, M. G.; Gessner, F.; Cione, A. P. P.; Sartori, R. A. and Cavalheiro, C. C. S. (2000), Interações entre corantes e argilas em suspensão aquosa. Química Nova, 23 : (6), 818-824.

Peterson, J.; Dwyer, J. (2000), An Informatics Approach to Flavonoid Database Development, J. Food Composition and Analysis, 13, 441-454.

Reed, J. S. (1998), Principles of ceramics processing, Wiley-Interscience Publication. pp. 588-595.

Renaud, S.; De Lorgeril, M. (1992), Wine, alcohol, platelets, and the French paradox for coronary heart disease. The Lancet, 339 : (8808), 1523-1526.

Stringheta, P. C. (1991), Identificação da estrutura $e$ estudo da estabilidade das antocianinas extraídas da inflorescência de capim gordura (Mellinis minutuflora, Pal de Beauv.). Tese, UNICAMP, Campinas-SP.

Van Olphen, M. and Fripiat, J. J. (1979), Data handbook for clay materials and other non-metallic minerals. Oxford : Pergamon Press. 346 pp.

Received: September 29, 2004; Revised: February 25, 2005; Accepted: March 25, 2005. 